\title{
Irrigation System Descriptions for Tropical and Subtropical Fruit Crops in Florida ${ }^{1}$
}

\author{
Jonathan Crane, Haimanote Bayabil, Edward A. Evans, and Fredy Ballen²
}

\section{Introduction}

Florida has a diverse and vibrant tropical fruit industry of about 14,562 acres with an estimated economic impact of greater than $\$ 300$ million to the state's economy (Crane 2018; Evans and Ballen, personal communication). Commercial subtropical fruit crops include but are not limited to avocado, carambola, dragon fruit (pitaya), guanabana (soursop), guava, jackfruit, longan, lychee, mamey sapote, mango, papaya, passionfruit, sapodilla, and sugar apple.

To meet crop water needs and for freeze protection in certain areas, irrigation is a key cultural input for subtropical and tropical fruit production in Florida. Irrigation during dry periods prevents drought stress that may result in a delay to full production, nutrient deficiencies, and reduced fruit set, fruit yields, and quality (Goldweber and Colburn 1971). Cold protection of tropical and subtropical fruit crops in Florida becomes necessary during freeze events, which occur periodically (e.g., Campbell et al. 1977, Ledin 1958, Lynch 1940, Williamson and Crane 2010). Many types of irrigation systems have been utilized by Florida's tropical fruit industry, and each has advantages and disadvantages with respect to use, infrastructure requirements, management, costs, and potential for freeze protection.
There are numerous considerations and decisions to be made in the design and installation of an irrigation system, including type of system and the proper engineering to meet the system's needs (Bayabil et al. 2020, Boman and Shukla 2017, Boman and Shukla 2018, Boman et al. 2019, Haman and Zazueta 2017a, Haman and Zazueta 2017b). Irrigation system water-use and application efficiency vary by the type and management of the irrigation system (Smajstrala et al. 2002, Haman et al. 2002). Irrigation best management practices (BMPs) to meet crop water needs and prevent drought stress and nutrient leaching are addressed in other publications available through the UF/ IFAS Extension Electronic Data Information System (EDIS) at https://edis.ifas.ufl.edu.

Different types of high- and low-volume irrigation systems are commonly used for tropical and subtropical fruit crop production in Florida. New and prospective tropical fruit producers need information to make an informed choice as to which irrigation system may meet their irrigation and freeze protection needs. The choice of an irrigation system depends on several factors. The objective of this publication is to describe and comment on the major types of irrigation systems currently used by the tropical fruit industry of Florida.

1. This document is HS1375, one of a series of the Horticultural Sciences Department, UF/IFAS Extension. Original publication date September 2020. Visit the EDIS website at https://edis.ifas.ufl.edu for the currently supported version of this publication.

2. Jonathan Crane, professor, Horticultural Sciences Department; Haimanote Bayabil, assistant professor, Department of Agricultural and Biological Engineering; Edward A. Evans, professor, Food and Resource Economics Department; and Fredy Ballen, data management analyst, agricultural economics; UF/IFAS Tropical Research and Education Center, Homestead, FL 33031.

The Institute of Food and Agricultural Sciences (IFAS) is an Equal Opportunity Institution authorized to provide research, educational information and other services

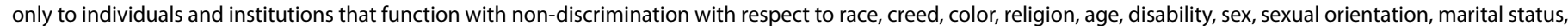

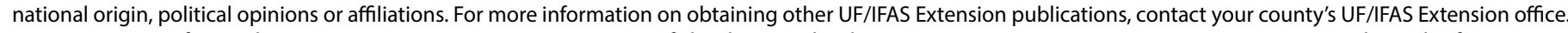
U.S. Department of Agriculture, UF/IFAS Extension Service, University of Florida, IFAS, Florida A \& M University Cooperative Extension Program, and Boards of County Commissioners Cooperating. Nick T. Place, dean for UF/IFAS Extension. 


\section{High-Volume Overhead Irrigation Systems (8-to-15-foot-tall risers)}

High-volume overhead irrigation systems are used for irrigation and freeze protection (Figure 1). High-volume overhead irrigation systems consist of buried mainlines connected to 8-15 ft tall metal pipes generally spaced at 40-60 $\mathrm{ft}$ apart throughout the grove and topped with high-impact sprinklers. These systems are designed to apply $0.2-0.25$ inches of water per acre per hour or more. They are usually powered by a diesel or gas engine and pump, are designed to run at 30-60 psi, have an output of about 91-113 gallons per minute (gpm), have a spray radius of up to 30 feet ( $30 \%$ overlap among sprinklers), and are designed for complete land coverage. Typically in these systems, impact sprinklers spray water on a $360^{\circ}$ radius at $\sim 45^{\circ}$ trajectory, and depending upon output pressure, spray 5-7 ft above $90^{\circ}$. Typically, these high-volume systems are not automated but managed manually (i.e., turned on and off).

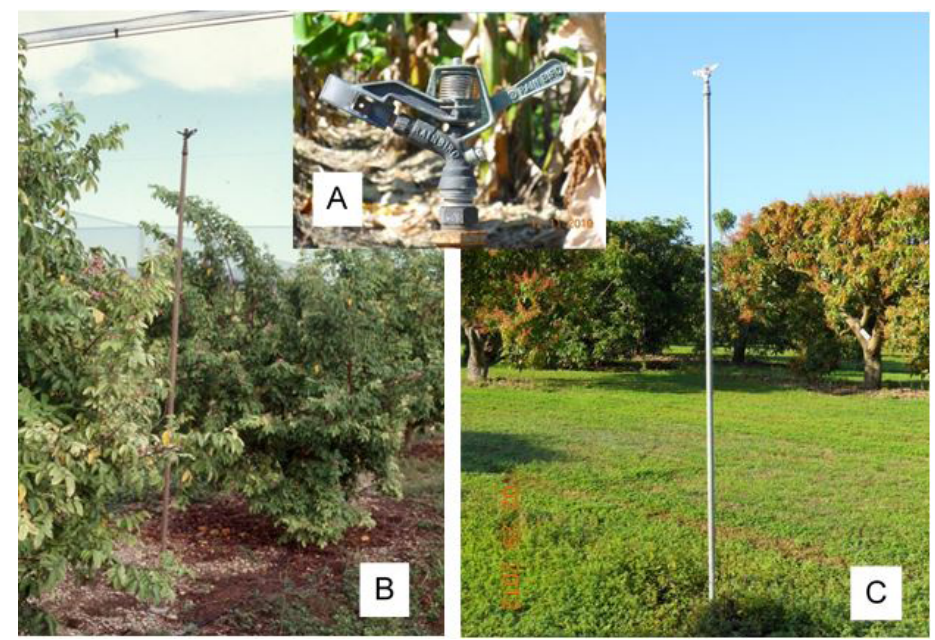

Figure 1. High-volume overhead irrigation pipe (metal pipe, 10 to $15 \mathrm{ft}$ high) with brass high-impact sprinkler head (A) in a carambola grove (B) and a mango grove (C).

Credits: J. H. Crane, UF/IFAS TREC

\section{Advantages}

1. High-volume overhead irrigation systems provide irrigation and freeze protection to trees. Freeze protection potential depends upon pumping capacity, water distribution pattern, and management of the system.

2.High-volume overhead irrigation systems are designed to cover nearly all the grove land surface area with water in an overlapping pattern. This is important for the shallowly rooted fruit trees planted in Miami-Dade County, where land consists of well-drained crushed oolitic limestone about 6 to 8 inches deep. The grove may or may not also be transected in a grid pattern of 16-to-24-inch-deep by 45-inch-wide trenches (Colburn and Goldweber 1961). These systems provide water to most of the lateral tree root system.

\section{Disadvantages}

1. Freeze damage may occur if the system is not designed for sufficiently high water output and complete canopy coverage or is not managed properly during a freeze event.

2. During prolonged freezing weather events, accumulation of ice on tree limbs may cause them to break. On occasion the trunk splitting may cause further damage.

3. During advective freezes when winds may be $>5 \mathrm{mph}$, the water distribution pattern may be distorted and result in parts of the tree canopy to experience evaporative cooling and be damaged or killed.

4. Irrigation application efficiency ranges from $60 \%-80 \%$ with an average of 75\% (Smajstrla et al. 2002). Efficiency declines rapidly due to increased evaporation during windy or dry air conditions.

5. High-volume overhead systems require large pump capacity and engines to operate properly. Purchase and operational costs are generally higher than low-volume systems (Table 1).

While effective, these systems have gone out of favor during freeze events due to the potential for branch and trunk breakage when the weight of the ice accumulated along the tree branches and trunk. In addition, installing these systems (i.e., the cost of large pumps and engines and metal piping) and maintenance for these tall metal pipes with impact sprinklers is expensive.

\section{High Volume Under-Tree Irrigation Systems (2-to-5-Foot-Tall Risers)}

High-volume under-tree irrigation systems also provide irrigation and freeze protection (Figure 2). These systems are more common than overhead systems, and some overhead systems have been modified (i.e., lowered the pipe height and added more lateral lines) to under-tree systems. These systems generally cause much less ice accumulation and therefore less tree damage. Maintaining these short PVC or metal pipes is easier than overhead systems. However, due to the increased number of irrigation lines and pipes necessary along with the large pumps and engines, cost may be about the same as for the high-volume overhead systems. 
High-volume under-tree irrigation systems consist of buried mainlines connected to 2-5 ft tall metal or hard PVC pipes generally spaced 20-50 ft apart throughout the grove (depending upon row spacing) and topped with high-impact sprinklers. They are usually spaced so every other row and every second tree has a sprinkler between trees in-row (Figure 3 ). These systems are designed to apply $0.2-0.25$ inches of water per acre per hour. They are powered by either diesel or gas engines and pumps and are designed for an output of 30-50 psi, with an output of about 91-113 gallons per minute (gpm), a spray radius of up to 30 feet and complete land coverage. Impact sprinklers spray water on a $\sim 45^{\circ}$ angle and depending upon output pressure, spray 5-7 ft above $90^{\circ}$. Typically, these highvolume under-tree systems are not automated but managed manually (i.e., turned on and off).

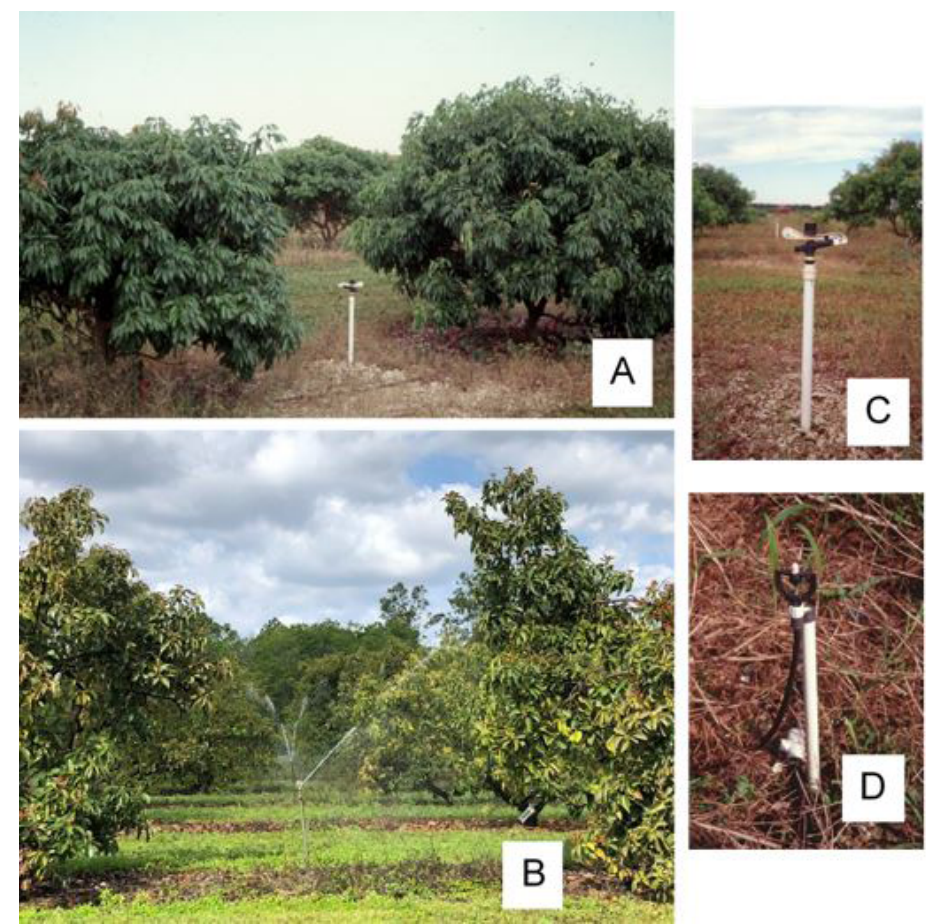

Figure 2. High-volume irrigation system with a $2 \mathrm{ft}$ high sprinkler (typically called under-tree irrigation) made of PVC pipe and plastic high-impact sprinkler head in a lychee grove (A), a system made of $3 \mathrm{ft}$ high metal pipe with brass high-impact sprinkler head in an avocado grove (B), a close-up of a $2 \mathrm{ft}$ PVC pipe and plastic high-impact sprinkler head (C), and a $2 \mathrm{ft}$ PVC pipe with high-impact spinner-type head (D).

Credits: J. H. Crane, UF/IFAS TREC

High-volume systems under tree must be properly designed because an insufficient number of risers or poor waterdistribution pattern (e.g., too wide apart, interference from tree canopies) results in uneven water distribution, and some trees or parts of trees may experience freeze damage by evaporative cooling.

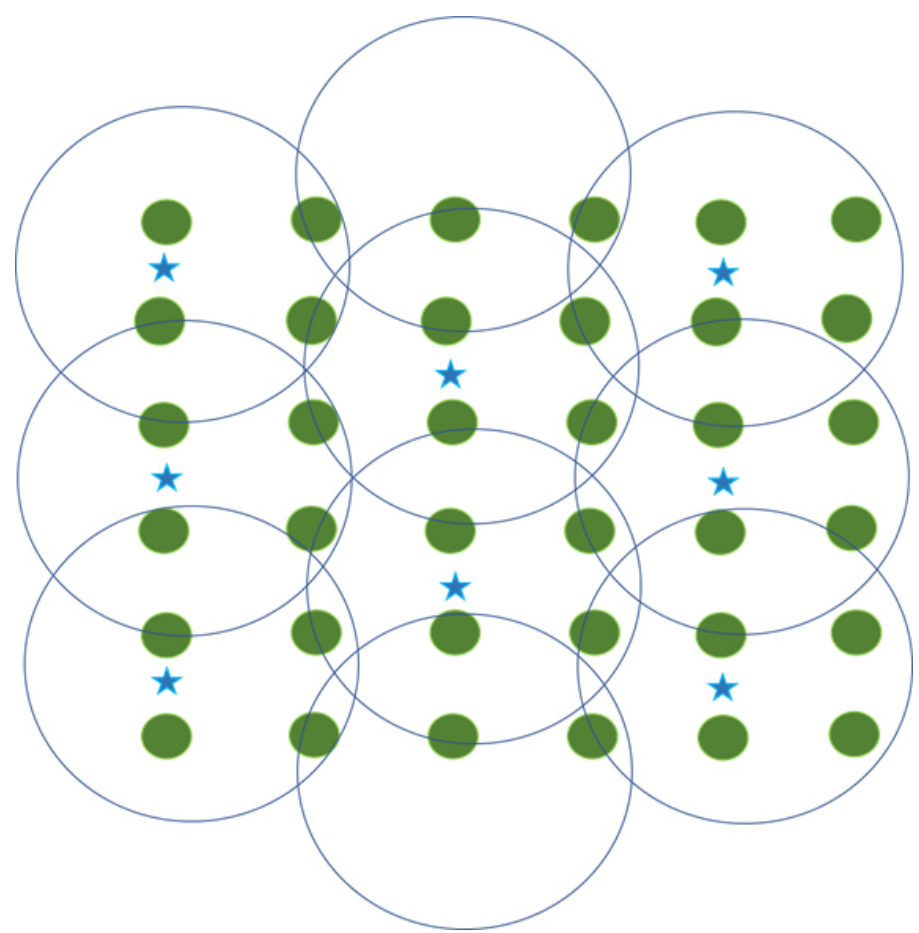

Figure 3. High-volume under tree irrigation impact sprinklers (star) arrangement in and between trees in the rows (green dot) and ground coverage (circles) (not to scale).

\section{Advantages}

1. This system provides irrigation and freeze protection to trees. However, because the distribution of water reaches only 5 to $7 \mathrm{ft}$ from the ground into the canopy, the canopy above about $9 \mathrm{ft}$ may be damaged. This is more of a problem for older/larger trees than younger/smaller trees; however, recovery from the upper-tree freeze damage is usually rapid. Generally, ice accumulation on the lower trunk and main limbs does not result in limb breakage because these lower limbs are stronger than upper limbs. These systems are now preferred over high-volume systems over tree for this reason.

2. Like overhead, these systems are designed to cover a large area of the grove surface area with an overlapping distribution pattern (Fig. 3). Similarly, for groves planted in Miami-Dade County these systems provide water to nearly all the lateral tree root system.

3. Irrigation application efficiency is potentially better than high-volume overhead systems if there is minimal tree canopy interference, mainly due to less wind distortion and evaporation.

\section{Disadvantages}

1.High-volume under-tree systems require large pumping capacity and engines to operate the system properly. 
Purchase and operational costs are generally higher than low-volume systems (Table 1).

2. There is potential for tree freeze damage if the wetting pattern is obstructed by adjacent or nearby trees.

\section{High-Volume Irrigation Placed inside the Tree Canopy (High- Volume In-Tree Systems)}

High-volume in-tree irrigation systems also provide irrigation and freeze protection (Figure 4). These systems are much less common than other high-volume systems. These systems generally result in much less ice loading and tree damage because of the high volume of water applied per acre. Maintaining these PVC or metal pipes is generally easier than the overhead systems, but the increased number of irrigation lines and pipes necessary (one for each tree) along with the large pumps and engines needed make this the most expensive high-volume system.
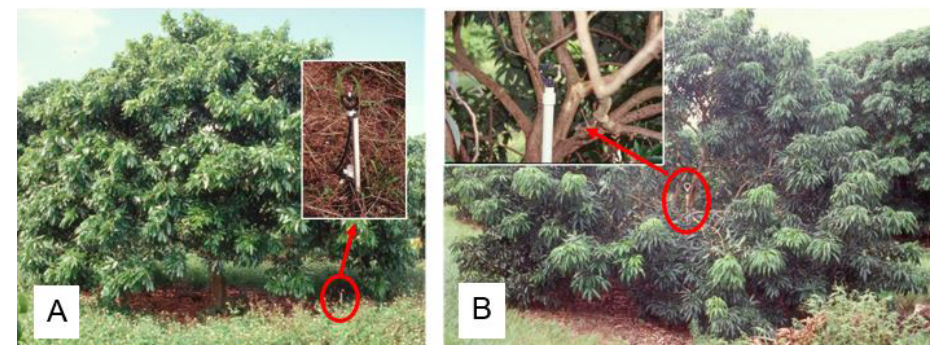

Figure 4. High-volume irrigation with PVC pipes with spinner-type high-impact sprinklers inside the tree canopy (typically called in-tree) of lychee trees. (A) High-volume sprinkler on 18-inch PVC pipe and (B) high-volume sprinkler on 5-foot-tall PVC pipe.

Credits: J. H. Crane, UF/IFAS TREC

High-volume in-tree irrigation systems consist of buried mainlines and submains connected to 2-9 $\mathrm{ft}$ tall hard PVC pipes placed $2-5 \mathrm{ft}$ adjacent to the trunk of each tree. The pipes are typically placed within the tree dripline and are topped with either a high-impact sprinkler or spinner-type sprinkler. These systems are designed to apply $0.20-0.40$ inches of water per acre per hour. They are powered by either diesel or gas engines and pumps and are designed for an operating pressure of 30-60 psi, with an output of 91-181 gallons per minute (gpm) and a spray radius dependent upon the size of the tree canopy area. In mature trees the distribution of water is mostly confined to the inside of the tree canopy. Like the other high-volume systems, most systems are not automated but managed manually (i.e., turned on and off).

\section{Advantages}

1. This system confines irrigation distribution to the canopy dripline around the trunk. Observations of these systems during freeze events indicate that very little ice accumulates on tree limbs and the trunk due to high volume of water and heat released during freeze events with this system.

2. This system provides excellent cold protection. It may be used for irrigation, but because of the high volume of water output and limited lateral water distribution, establishment of an additional low-volume irrigation system (e.g., microsprinkler) for meeting crop water needs may reduce annual water usage and energy costs.

3. The in-tree riser may be installed higher by adding a pipe and thereafter adjusting to increasing tree height as trees age.

4. Irrigation application uniformity is better than highvolume overhead and under-tree systems because of much less wind distortion and evaporation.

\section{Disadvantages}

1. The system usually requires a high-capacity pump and engine that have the capability to apply more than $0.25-0.40$ inches of water per acre per hour.

2. High-volume in-tree systems require large pump capacity and engines to operate the system properly. This is the most expensive irrigation system to purchase and operate (Table 1).

\section{Low-Volume Drip-Irrigation Systems}

Drip systems are very efficient at applying water to the soil surface and are commonly placed under plastic or organically mulched beds (Figure 5). Drip is used primarily for papaya and banana production in Florida. The output of drip irrigation depends upon the pump pressure, tube sizing, number and size of emitters, and number of tubes per plant bed. However, they provide no cold protection. These systems may be powered by $5 \mathrm{hp}$ electric or fuel engines and pumps, may be modified to inject fertilizers, and are generally automated. The cost of drip systems is less than the high-volume and microsprinkler systems (Table 1). 


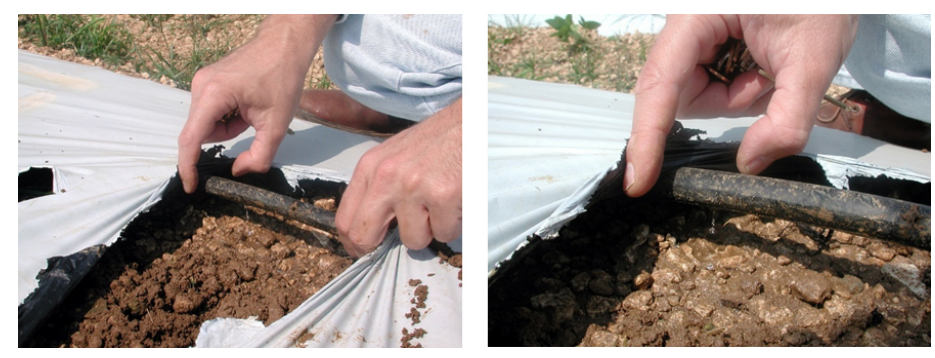

Figure 5. Low-volume drip tubing underneath plastic mulch. Photo credit:

Credits: J. H. Crane, UF/IFAS TREC

\section{Advantages}

1. Properly managed, these systems use low volumes of water and directly apply water to the root zone. They may be managed to meet crop needs and, if properly operated, minimize leaching of nutrients beyond the root zone (rhizosphere).

2. Fertilizers and other chemicals can be distributed through properly designed and equipped injection systems.

3. These systems require less pressure to pump water than high-volume systems; therefore, smaller pumps and engines can be used. Generally, low-volume drip systems are less expensive to install and maintain than high-volume systems. However, regular maintenance is necessary to prevent or correct clogging of the emitters or drip-tubing.

4. Irrigation application efficiency is higher than in highvolume systems and ranges from $70 \%-90 \%$, with an average of $85 \%$ (Smajstrla et al. 2002).

5. These systems are ideal for plastic- or organic-mulch bedded planting systems where the water is generally confined to the bed soil volume.

6. Drip systems are generally less costly to install and maintain than high-volume systems (Table 1).

\section{Disadvantages}

1. The lateral spread of water is limited in sandy soils of Florida and the oolitic limestone-based soils in MiamiDade County. This may not be too important for young woody trees, but for mature woody trees, most of their root system is well beyond the dripline, and therefore drip systems may not be capable of meeting crop water needs.

\section{These systems do not provide freeze protection.}

3. Due to the low pressures used to move water, clogging of the emitters can be a problem. Clogging can be caused by particulate matter (dirty water), proliferation of microorganisms, chemical precipitation (Liu and McAvoy 2018), and chemical residues.

4. Tubing on the soil surface is easily damaged by sunlight, rodents, and wildlife, and as a result it requires frequent maintenance and replacement of parts.

\section{Low- and High-Volume Microsprinkler Irrigation Systems}

Low- and high-volume microsprinkler systems are efficient at applying water to much of the tree root system area from the trunk to the canopy dripline when managed properly. Their use in cold protection depends upon their capacity for water output and management during a freeze event. Like drip systems, microsprinkler systems may be designed to inject agrochemicals through the system. These systems may be powered by electric or diesel/gas fuel engines and pumps and are generally automated. The cost of microsprinkler systems is lower than that of the high-volume overhead, under-tree, and in-tree systems, but higher than for drip systems (Table 1).

Depending upon system design and components, microsprinkler systems are designed to apply water within a confined radius and/or wetting pattern (Parsons and Morgan 2017) (Figure 6). The systems are generally composed of an electric motor and pump, buried main and submain lines, aboveground flexible lateral-line tubing, and hard plastic stakes with an emitter. There is a huge selection of emitters that influence the spray volume and uniformity of irrigation water distribution (Smajstrla et al. 2018). Depending upon the system design and pumping pressure these systems may be classified as low-volume systems, 5-10 gal per emitter per hour, or high-volume, $>15$ gal per emitter per hour.

With tropical and subtropical fruit crops, there is very little experience using microsprinkler systems for freeze protection. For example, young sapodilla trees 1-3 years old were successfully protected from freezing temperatures $\left(31^{\circ} \mathrm{F}\right.$; December $27-28,2010$ ) by a high-volume microsprinkler irrigation system used in conjunction with fiberglass batting installation of trunk wraps and placement of the emitters about $3 \mathrm{ft}$ high in the tree canopy (J. H. Crane, personal communication; NOAA-NWS 2010) (Figure 7). In contrast, there is a wealth of information on microsprinkler freeze protection for citrus (e.g., Oswalt and Vashisth 2019, Parsons and Boman 2019, Parsons et al. 1991). However, 
for most tropical fruits there is no experience using these systems during a prolonged or very cold freeze event.
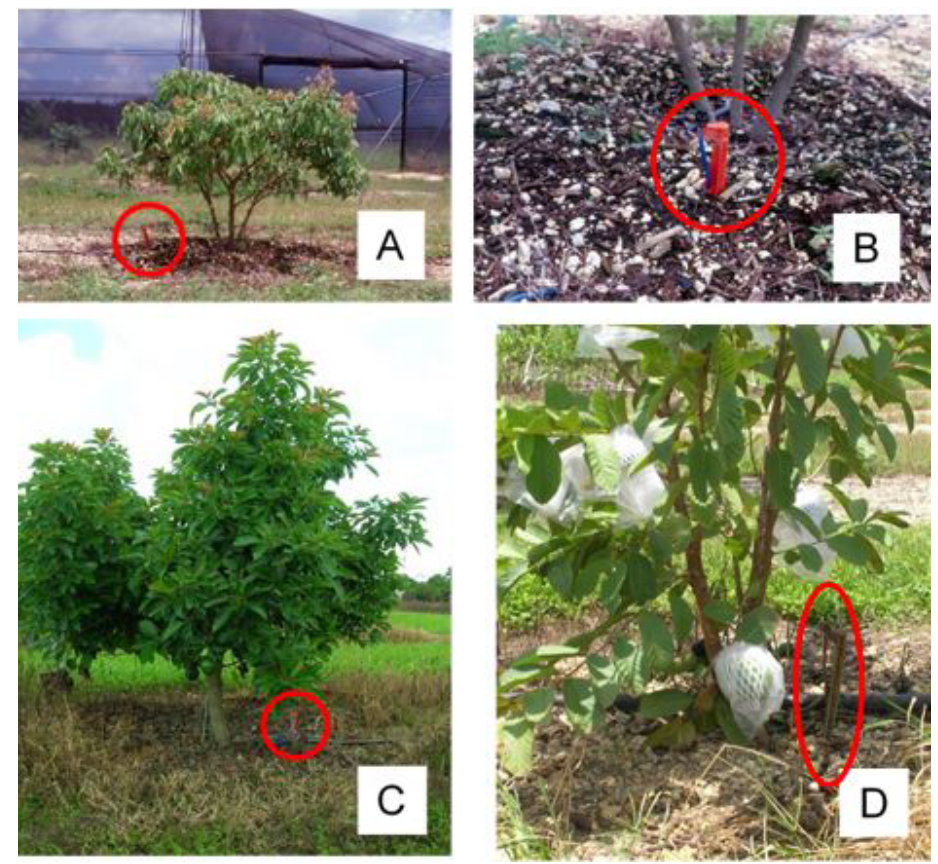

Figure 6. Microsprinkler irrigation in a young lychee grove (A and B), avocado grove (C) and guava grove (D).

Credits: J. H. Crane, UF/IFAS TREC

For freeze protection of young trees, the ground-based microsprinklers need to be located on the north or northwest side of the tree, 2 to 3 feet away from the tree trunk. This allows winds during advective freeze (windy freezes) events to blow water toward the tree. The best emitters for freeze protection are fan-type of either $90^{\circ}$ or $180^{\circ}$ wetting pattern that concentrate their spray onto the lower portion of the tree canopy and trunk. Alternatively, microsprinklers with $360^{\circ}$ fan-type microsprinklers may be placed on 24-to-36-inch-high stakes in the center of the tree canopy ( 2 to 4 inches from the trunk) of young trees (Figure 7 ). The emitter tubing needed is much longer than ground-based microsprinklers and should be wrapped around the stake to keep ice formation from pulling down the elevated emitter. In conjunction with microsprinklers the installation of high-insulating-value tree wraps provides additional freeze protection to young trees (Oswalt and Vashisth 2019, Parsons and Boman 2019, Rieger et al. 1986). Tree wraps should have a high insulation R-value, which indicates its resistance to heat flow (or loss). Tree wraps made of fiberglass batting have a relatively high $\mathrm{R}$-value (2.9-3.8) (Figure 7).

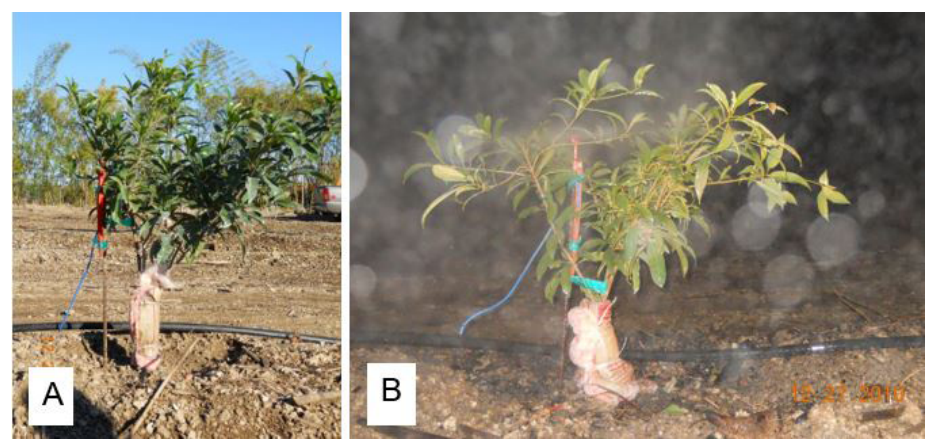

Figure 7. Young sapodilla tree with a fiberglass batting tree trunk wrap and elevated microsprinkler $(A)$ prior to and $(B)$ during the December 27-28, 2010 freeze event in Homestead, Florida.

Credits: J. H. Crane, UF/IFAS TREC

\section{Advantages}

1. A larger area and volume of soil and rhizosphere is irrigated with these systems compared to drip systems.

2. Properly used, these systems direct the application of water to the root zone area of one tree or two adjacent trees (placement is critical).

3. Fertilizers and other chemicals may be distributed through properly designed and equipped systems (Clark et al. 2017, Haman and Zazueta 2017b).

4. Irrigation application efficiency is higher than highvolume overhead, under-tree, and in-tree systems and ranges from $70 \%-85 \%$, with an average of $80 \%$ (Smajstrla et al. 2002). Efficiencies decline in young plantings where sprinklers are more exposed to windy conditions.

5. These systems require less pump pressure to distribute water than high-volume overhead, under-tree, and in-tree systems, and therefore smaller pumps and engines may be used.

6. Generally, low-volume microsprinkler systems are less expensive to install and maintain than high-volume systems, but they cost more than drip systems (Table 1).

\section{Disadvantages}

1. The low-volume microirrigation systems provide little to no freeze protection. This is because the volumes of water applied are too low, and distribution patterns (plant coverage) are generally insufficient to protect tropical and subtropical fruit trees during freezing weather events. Winds of $>5 \mathrm{mph}$ can alter the application pattern, often resulting in uneven water distribution and evaporative cooling of plant surfaces. 
2. Due to the low pressures used to distribute water, clogging of the emitters can be a problem. Clogging can be caused by particulate matter (dirty water), microorganisms, and chemical residues.

\section{Summary}

High- and low-volume irrigation systems are used by Florida's subtropical and tropical fruit industry. Historically, high-volume systems were installed and used for irrigation and freeze protection. As the water-use and fuel efficiency of low-volume systems became apparent, some producers installed these systems along with their high-volume systems, limiting the high-volume system use to freeze protection. During the last decade, many new groves and older established groves have installed microsprinkler irrigation systems. Many of these may not have the capacity to afford much freeze protection for tropical fruit trees, especially young trees. Current, new, and potential tropical and subtropical fruit producers should carefully review the water requirements and cold and freeze tolerance needs of their fruit crops and install or upgrade an existing system to meet those needs.

\section{Literature Cited}

Bayabil, H. K., K. W. Migliaccio, M. Dukes, and L. Vasquez. 2020. Basic Tips for Designing Efficient Irrigation Systems. AE539. Gainesville: University of Florida Institute of Food and Agricultural Sciences. https://edis.ifas.ufl.edu/ae539

Boman, B., and S. Shukla. 2017. Materials and Installation of Delivery Pipes for Irrigation Systems. CIR1424. Gainesville: University of Florida Institute of Food and Agricultural Sciences. https://edis.ifas.ufl.edu/ch171

Boman, B., and S. Shukla. 2018. Hydraulic Considerations for Citrus Microirrigation Systems. Cir1425. Gainesville: University of Florida Institute of Food and Agricultural Sciences. https://edis.ifas.ufl.edu/ch156

Boman, B., S. Shukla, and J. D. Hardin. 2019. Design and Construction of Screened Wells for Agricultural Systems. Circular 1454. Gainesville: University of Florida Institute of Food and Agricultural Sciences. https://edis.ifas.ufl.edu/ ch166

Campbell, C. W., R. J. Knight, Jr., and N. L. Zareski. 1977. "Freeze Damage to Tropical Fruits in Southern Florida in 1977." Proc. Fla. State Hort. Soc. 90:254-257.
Clark, G. A., D. Z. Haman, and F. S. Zazueta. 2017. Injection of Chemicals into Irrigation Systems: Rates, Volumes and Injection Periods. BUL250. Gainesville: University of Florida Institute of Food and Agricultural Sciences. https://edis.ifas. ufl.edu/ae116

Colburn, B., and S. Goldweber. 1961. "Preparation of Oolitic Limestone Soil for Agricultural Use." Proc. Fla. State Hort. Soc. 74:343-345.

Crane, J. H. 2018. "Tropical Fruit Production in FloridaTrials, Tribulations, and Opportunities." Proc. Fla. State Hort. Soc. 131:ix-xii.

Goldweber, S., and R. E. Colburn. 1971. "Irrigation of Tropical and Subtropical Fruit Groves in Dade County, Florida." Proc. Fla. State Hort. Soc. 84:278-281.

Haman, D. Z., A. G. Smajstrla, and D. J. Pitts. 2002. Efficiencies of Irrigation Systems Used in Florida Nurseries. BUL312. Gainesville: University of Florida Institute of Food and Agricultural Sciences. https://ufdcimages.uflib.ufl.edu/ IR/00/00/15/01/00001/AE08700.pdf

Haman, D. Z., and F. S. Zazueta. 2017a. Measuring Pump Capacity for Irrigation System Design. CIR1133. Gainesville: University of Florida Institute of Food and Agricultural Sciences. https://edis.ifas.ufl.edu/ae067

Haman, D. Z., and F. S. Zazueta. 2017b. Chemical Injection Methods for Irrigation. CIR864. Gainesville: University of Florida Institute of Food and Agricultural Sciences. https:// edis.ifas.ufl.edu/wi004

Ledin, R. B. 1958. "Cold Damage to Fruit Trees at the Sub-tropical Experiment Station, Homestead." Proc. Fla. State Hort. Soc. 71:341-344.

Liu, G. D., and G. McAvoy. 2018. How to Reduce Clogging Problems in Fertigation. HS1202. Gainesville: University of Florida Institute of Food and Agricultural Sciences. https:// edis.ifas.ufl.edu/hs1202

Lynch, S. J. 1940. “Observations on the January 1940 Cold Injury to Tropical and Subtropical Plants." Proc. Fla. State Hort. Soc. 53:192-194.

NOAA-NWS. 2010. "NOAA, National Weather Service, Weather Forecast Office. South Florida Freeze and Frost, December 28, 2010." https://weather.gov/southflorida 
Oswalt, C., and T. Vashisth. 2019. 2019-2020 Florida

Citrus Production Guide: Citrus Cold Protection. CMG18.

Gainesville: University of Florida Institute of Food and

Agricultural Sciences. https://edis.ifas.ufl.edu/cg095

Parsons, L. R., and B. J. Boman. 2019. Microsprinkler Irrigation for Cold Protection of Florida Citrus. HS931. Gainesville: University of Florida Institute of Food and Agricultural Sciences. https://edis.ifas.ufl.edu/ch182

Parsons, L. R., and K. T. Morgan. 2017. Management of Microsprinkler Systems for Florida Citrus. HS958. Gainesville: University of Florida Institute of Food and Agricultural Sciences. https://edis.ifas.ufl.edu/hs204

Parsons, L. R., A. Wheaton, N. D. Faryna, and J. L. Jackson. 1991. "Elevated Microsprinklers Improve Protection of Citrus Trees in an Advective Freeze." HortScience 26:1149-1151.

Rieger, M., F. S. Davies, and L. K. Jackson. 1986. "Microsprinkler Irrigation and Microclimate of Young Orange Trees during Freeze Conditions." HortScience 21:1372-1374.

Smajstrla, A. G., B. J. Boman, G. A. Clark, D. Z. Haman, F. T. Izuno, D. J. Pitts, and F. S. Zazueta. 2002. Efficiencies of Florida Agricultural Irrigation Systems. BUL247. Gainesville: University of Florida Institute of Food and Agricultural Sciences. https://ufdc.ufl.edu/IR00004382/00001

Smajstrla, A. G., B. J. Boman, D. Z. Haman, D. J. Pitts, and F. S. Zazueta. 2018. Field Evaluation of Microirrigation Water Application Uniformity. BUL265. Gainesville: University of Florida Institute of Food and Agricultural Sciences. https://edis.ifas.ufl.edu/ae094

Williamson, J. G., and J. H. Crane. 2010. "Best Management Practices for Temperature and Tropical/Subtropical Fruit Crops in Florida: Current Practices and Future Challenges." HortTechnology 20 (1): 111-119.

Zazueta, F. S., and D. Z. Haman. 2017. Potential Impacts of Improper Irrigation System Design. AE73. Gainesville: University of Florida Institute of Food and Agricultural Sciences. https://edis.ifas.ufl.edu/ae027 
Table 1. Range in cost to establish and maintain high- and low-volume irrigation systems for one acre of tropical fruit production in south Florida.

\begin{tabular}{|l|c|c|}
\hline \multicolumn{1}{|c|}{ System type } & Cost to establish (\$) & Cost to maintain per year (\$) \\
\hline High volume over tree & $7,000-8,000$ & $100-200$ \\
\hline High volume under tree & $7,300-8,400$ & $100-200$ \\
\hline High volume in-tree & $8,000-9,000$ & $100-300$ \\
\hline Drip system with injection capability & $1,200-2,000$ & $250-300$ \\
\hline Low-volume microsprinkler with injection capability & $2,000-3,000$ & $300-350$ \\
\hline High-volume microsprinkler with injection capability & $2,500-3,500$ & $300-350$ \\
\hline
\end{tabular}

